MaPan : Jurnal Matematika dan Pembelajaran

p-ISSN: 2354-6883 ; e-ISSN: 2581-172X

Volume 8, No 2, Dec 2020 (281-299)

DOI: https://doi.org/10.24252/mapan.2020v8n2a8

\title{
MATHEMATICAL LITERACY ABILITY OF CAMPER TYPE STUDENTS BASED ON GENDER DIFFERENCES
}

\author{
Ma'rup1), Andi Husniati2), Muhammad Rizal Usman'3), Kristiawati') \\ 1,2,3,4Universitas Muhammadiyah Makassar \\ 1,2,3,4Jalan Sultan Alauddin, Kota Makassar \\ Email:ma'rup@unismuh.ac.id11), andi.husniati@gmail.com²), \\ rizal.usman@unismuh.ac.id3), kristiawatidahlan@yahoo.co.id4)
}

Received December 05, 2020; Revised December 17, 2020; Accepted December 26, 2020

\begin{abstract}
:
This study illustrated the mathematical literacy ability of camper type students based on gender differences. The subject of this study were class X MIA students of SMAN 2 Takalar. This study is a descriptive study with a qualitative approach design. The data processed is Adversity Quotient data and students' mathematical literacy abilities data. Adversity Response Profile (ARP) questionnaire was used to find out students with camper type. The test used to see the mathematical literacy ability of male and female students with camper type is PISA (Programme for International Student Assessment) question consists of three questions. Interviews were conducted to further explore students' mathematical literacy ability. Based on the data analysis, it was found that the mathematical literacy ability of the camper type female student was higher than the camper type male student.
\end{abstract}

Keywords: Mathematics Literacy Ability, Camper Type, Gender

\section{KEMAMPUAN LITERASI MATEMATIKA SISWA TIPE CAMPER BERDASARKAN PERBEDAAN GENDER}

\begin{abstract}
Abstrak:
Penelitian ini mendeskripsikan kemampuan literasi matematika siswa tipe camper berdasarkan perbedaan gender. Subjek penelitian ini adalah siswa kelas X MIA SMAN 2 Takalar. Penelitian ini merupakan penelitian deskriptif dengan pendekatan kualitatif. Data yang diolah adalah data Adversity Quotient untuk siswa tipe camper dan data kemampuan literasi matematika siswa. Angket Adversity Response Profile (ARP) digunakan untuk memilih siswa tipe camper. Soal yang digunakan untuk melihat kemampuan literasi matematika siswa perempuan dan laki-laki tipe camper adalah soal PISA (Programme for International Student Assesment) yang berjumlah 3 nomor. Wawancara dilakukan untuk lebih menggali kemampuan literasi matematika siswa. Berdasarkan analisis data, diperoleh bahwa kemampuan literasi matematika siswa perempuan tipe camper lebih tinggi daripada kemampuan literasi matematika siswa laki-laki tipe camper.
\end{abstract}

Kata Kunci : Kemampuan Literasi Matematika, Tipe Camper, Gender 
How to Cite: Ma'rup, Husniati, A., Usman, M. R., \& Kristiawati. (2020). Mathematics Literacy Ability of Camper Type Students Based on Gender Differences. MaPan : Jurnal $\begin{array}{llll}\text { Matematika dan } & \text { Pembelajaran, 281-299. }\end{array}$ https://doi.org/10.24252/mapan.2020v8n2a8.

\section{INTRODUCTION}

ccording to the formulation of the Ministry of Education and Culture
emphasizes the ability of students to find out from various sources. The
development of the 21st century is marked by the use of information and communication technology in all human life, including in the learning process (Daryanto \& Syaiful, 2016). Besides technology, education is one of the benchmarks for the progress of a nation, therefore to find out the progress of a nation can be seen from how much human resources a country has, with reliable human resources it will give birth to scientific thoughts that will bring about change. Mathematics is an effort to improve the abilities of students and increase the intelligence of students. In this case, mathematical concepts are used as tools to develop these mathematical abilities.

According to National Council of Teachers of Mathematics (2000) in the book Abidin, Mulyati, and Yunansah (2017) about the definition of five mathematical abilities in mathematics learning. These five abilities are abilities that must be mastered by students after learning mathematics, namely mathematical reasoning, mathematical representation, mathematical connections, mathematical communication, and mathematical problems.

Mathematical literacy is an individual's capacity to formulate, employ, and interpret mathematics in a variety of contexts. It includes reasoning mathematically and using mathematical concepts, procedures, fact and tools to describe, explain and predict phenomena. It assists individuals in recognizing the role that mathematics plays in the world and to make the well-founded judgments and decisions needed by constructive, engaged, and reflective citizens (OECD, 2015: 13; White, 2018).

This means that mathematical literacy is the ability of students to formulate, use, and interpret mathematics in various contexts. This includes mathematical reasoning using mathematical concepts, procedures, facts, and tools to describe, explain, and predict phenomena. This helps one to recognize the role of mathematics in life and to make rational and logical judgments and decisions that are required by constructive, actively engaged, and reflective 
citizens.

According to Kern in Mahdiansyah and Rahmawati (2014), literacy learning is characterized by three R's, namely responding, revising, and reflecting. Responding involves both parties, teachers and students. Students respond to assignments given by the teacher or to the texts they read. The revision includes various language activities. Reflecting is concerned with evaluating what has been done, what was seen, and what was felt when learning was carried out (Wicaksana, Wardono, \& Ridlo, 2017).

OECD (2014: 39) defines mathematical literacy as a person's ability to formulate, apply, and interpret mathematics in various contexts including the ability to do mathematical reasoning, while Ojose (2011: 89) said that mathematical literacy is the knowledge to know and use the basics of mathematics in everyday life. In this case, students are able to apply mathematics by relating it to the real world students. Dorn and Jones (1980) states that there are four levels of literacy, namely performative, functional, informational, and epistemic.

Students' mathematical literacy ability is assessed using an international level assessment study, namely PISA (Program for International Student Assessment). Indonesia has joined as a member of PISA (specifically in the assessment of mathematics literacy) along with other countries, such as Singapore, China, and the UK. However, the results show that Indonesia's ranking is still far from expectations. In 2018, Indonesia was ranked 63rd with a score of 379 out of 72 participating countries.

Table 1. Indonesia's Participation in PISA For 18 Years

\begin{tabular}{ccccc}
\hline Year Studi & Subjects & Indonesian Rating & Score & Participants \\
\hline 2000 & Mathematics & 39 & 367 & 41 \\
2003 & Mathematics & 38 & 360 & 41 \\
2006 & Mathematics & 50 & 391 & 57 \\
2009 & Mathematics & 61 & 371 & 68 \\
2012 & Mathematics & 64 & 375 & 64 \\
2015 & Mathematics & 63 & 386 & 72 \\
2018 & Mathematics & 73 & 379 & 79 \\
\hline
\end{tabular}

Sources: Kemendikbud (2016)

The general objective of PISA is to assess the extent to which 15 years old students in OECD countries (and other countries) have acquired appropriate proficiency in reading, mathematics, and science to make a significant 
contribution to their society (Dorn \& Jones, 1980; Khoirudin, Styawati, \& Nursyahida, 2017).

Wardhani (2005) argues that PISA questions demand reasoning and problem solving skills. A student is said to be able to solve problems if he can apply previously acquired knowledge to new unfamiliar situations. This ability is what we usually know as high order thinking skills (Setiawan, Dafik, \& Lestari, 2014).

In assessing mathematical literacy skills, PISA makes it in the form of level consisting of six levels with level 1 as the lowest level and level 6 being the highest. In this study, the level of mathematical literacy skills used only level 1 to level 3 .

Table 2. Mathematical Literacy Ability Level according to PISA

\begin{tabular}{ll}
\hline 1 & Answering questions in a familiar context \\
& and all relevant information available with \\
& clear questions. \\
- & Identify information, and carry out common \\
& methods based on clear instructions. \\
- & Show action in accordance with the \\
& stimulation given. \\
- & Interpret and recognize situations in a \\
& context that require immediate conclusions. \\
- & Sorting relevant information from a single \\
& source, and using a single presentation \\
& method. \\
- & Work on basic algorithms, use formulas, \\
& carry out procedures or agreements. \\
- & Giving precise reasons for the results of the \\
& settlement \\
- & Carry out procedures clearly, including \\
& procedures that require consecutive \\
& decisions. \\
- & Solve problems, and apply simple strategies. \\
- & Interpret and use representations based on \\
different sources of information and state the \\
reasons why directly.
\end{tabular}

Sources: Syawahid and Putrawangsa (2017: 227) 
Looking at the results of the survey on mathematical literacy abilities issued by PISA, we can reflect that so far the ability of Indonesian students aged 15 years in mathematical literacy is still far from the average achievement of the survey participating countries. This is an indicator that Indonesian students' mathematical literacy skills are still considered low.

Some Indonesian researchers have also found low literacy skills of students in various regions of Indonesia, such as research conducted by Khoirudin, Styawati, and Nursyahida (2017) about: 1) the material chosen, 2) learning provided by the teacher, 3) classroom environment, 4) family environment support, and 5) readiness in the implementation of tests and 6) the abilities of each student himself.

Looking at some of the problems and facts above, the researcher tries to analyze the mathematical literacy skills of camper or students who have high AQ. Adversity Quotient has three levels, namely quitters, campers, and climbers. The climber type was the highest type and according to the researcher, the students who had climber type were students who were able to do the PISA questions in various ways and never gave up until they found the answer.

Based on the results of preliminary observations and interviews with mathematics teacher, students are dominant if given test questions and practice questions they will answer easy questions and do not try to continue to get answers to other questions, students are also easily satisfied with what they have achieved. These characteristics are the camper type so that the researcher is interested in studying the camper type students.

In this study, the researcher analyzes the mathematical literacy abilities of the camper type students based on gender. Many opinions said that male students are smarter than female students. As stated by Halpern in Goodwin and Friedman (2006) that boys have better intellectual abilities than girls. Boys are rational, independent, aggressive, achievement-oriented, and active. Meanwhile, girls are more proficient in reading and writing tasks. Because girls have a higher emotional level, give up easily, are passive and subjective, so they are weak in mathematics. Halpern's statement is reinforced by Sandra Witelson, a neuroscientist from Canada in Pasiak (2004: 94) in her research that the overall brain of girls is smaller than that of boys (Suryaprani, Suparta, \& Suharta, 2016).

According to Lange (2006: 14-15) in mathematical literacy, there are three categories of phenomena, namely spatial literacy, numeracy, and quantitative literacy. Basic mathematical literacy abilities that students must have involved seven components (OECD, 2015: 39), that communication, mathematizing, 
representation, reasoning and argument, devising a strategy for solving problems, and using symbolic, formal, and technical language and operation, using mathematical tools.

Therefore, researchers are motivated to research the description of mathematical literacy abilities of camper type students based on gender differences.

\section{METHODS}

The type of research used is descriptive qualitative research. Researchers used qualitative research as it aims to describe the mathematics literacy skills of students types camper based on gender differences of class X MIA SMAN 2 Takalar.

SMAN 2 Takalar is one of the schools that had participated in the PISA test in South Sulawesi. The instruments used were tests and interviews. The instrument test was a question of level 1, level 2, and level 3 to describe mathematical literacy skills and an interview test to find out the answer. ARP questionary was given to subjects to select students who had camper type. Implementation of giving ARP questionary before giving mathematics literacy questions. Activities in data analysis are categorization, reduction, display, and conclusion. The data analysis using the triangulation method, its comparing test results, and interviews.

\section{RESULTS AND DISCUSSION}

The activity of taking the Adversity Response Profile (ARP) questionnaire was conducted in class X MIA SMA Negeri 2 Takalar on Saturday, September 13, 2020, and was attended by 30 students. From ARP test results obtained 2 climber type students, 19 camper type students, and 9 quitter type students.

Subjects selection refers to the result of the highest score on the ARP questionnaire and is reinforced by the results of interviews with selected subjects. Besides, the subjects are able to communicate well when expressing themselves verbally or in writing and the subjects are willing to participate in the entire data collection process in this study. The name of the subjects written on the table is a pseudonym. Research subjects are presented in table 3. 
Table 3. Research Subjects

\begin{tabular}{clcc}
\hline No & Students & Score & AQ Type \\
\hline 1. & Alif & 130 & Camper \\
2. & Siti & 133 & Camper \\
\hline
\end{tabular}

Data analysis was performed by doing a sequence : (1) classification, (2) reduction, (3) presentation, (4) interpretation, (5) conclusion.

\section{a. Camper Type Female Subject (SP)}

1. Mathematical literacy ability of SP number 1

In June 2020, the new CDs of the Blackpink and Adele were released. In February, the CDs of BTS and the Maroon 5 followed. The following graph shows the sales of CDs from June to November.

\section{Sales Graph}
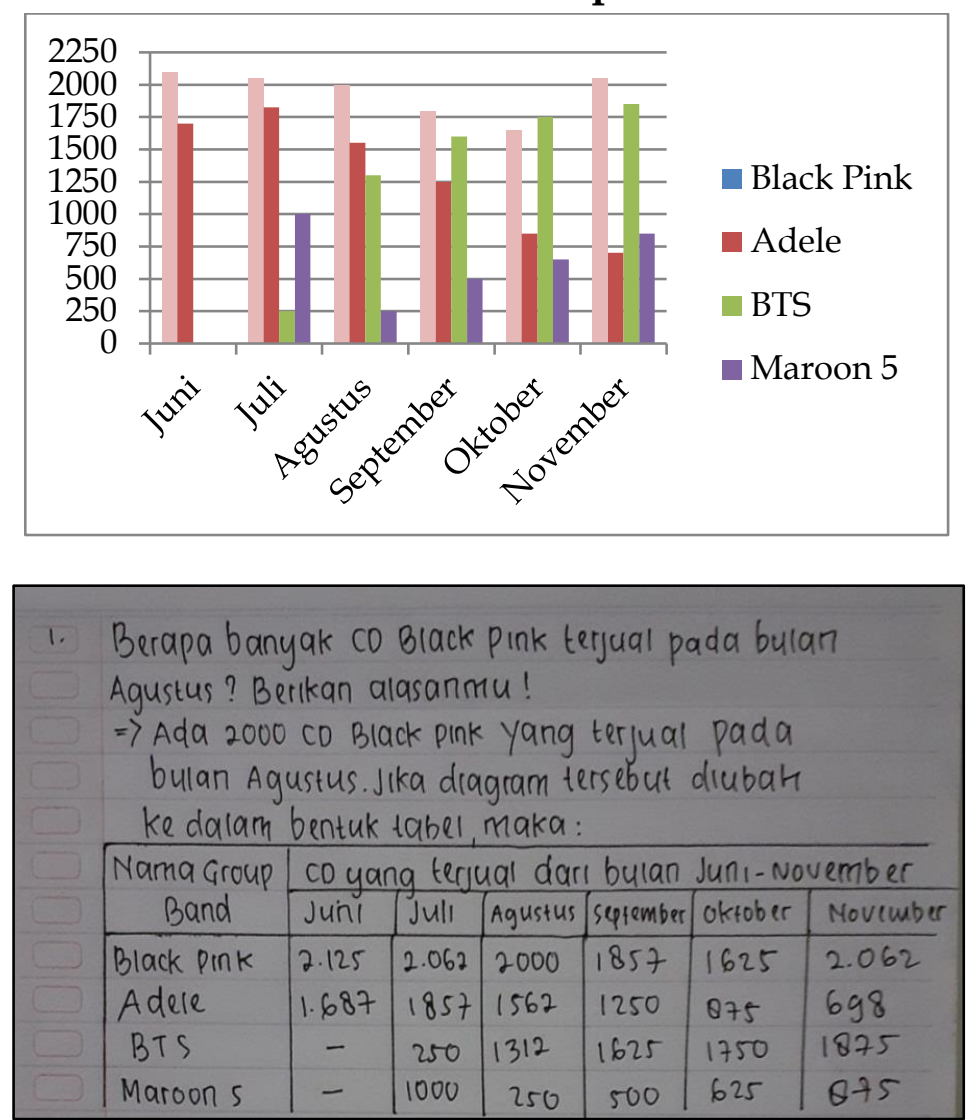

Figure 1. Female Student Answer to Question 1

\section{The researcher questions and subject answers}

P1-001: : : Hello Siti, look at the question, do you understand number 1 ?

SP1-001 : Yes sir.

P1-002 : Do you think the information on the questions is complete to answer the question? 


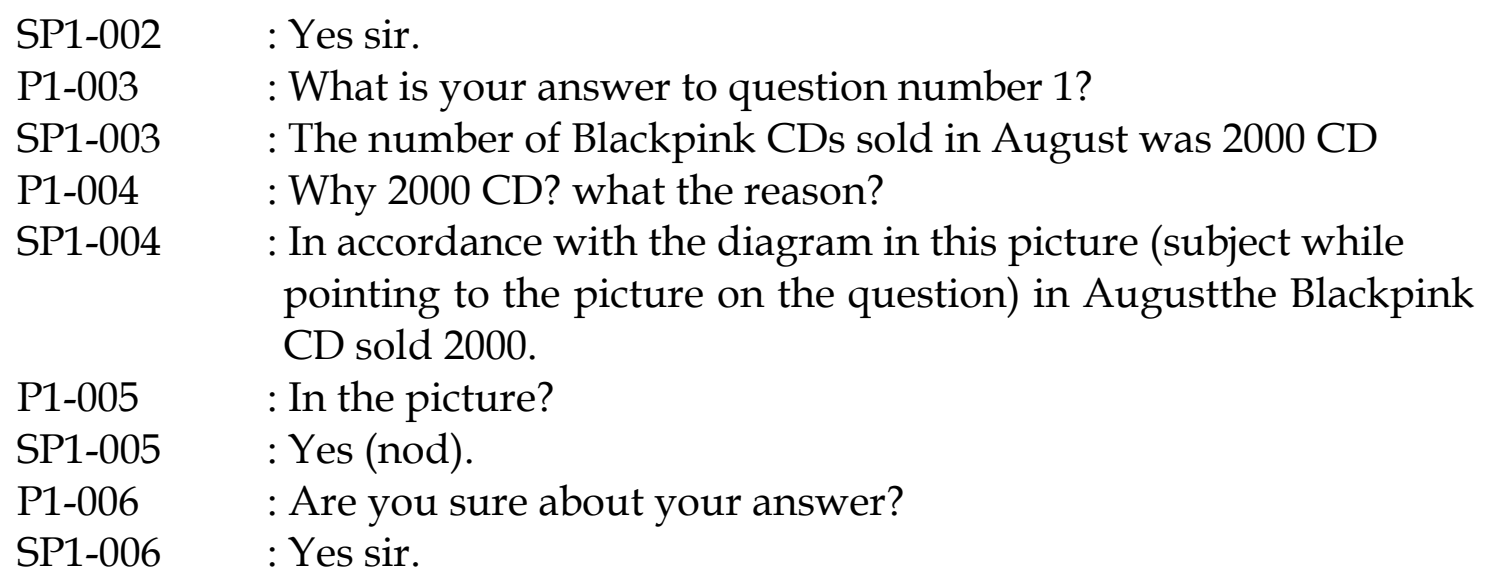

Following the data analysis process carried out in accordance with the student's mathematical literacy skills based on level 1. Subject answer from the PISA test results and the interview excerpt in question number 1 is correct, which is $2000 \mathrm{CD}$ and the reason given by she was very clear because the diagram was converted into form table whereas the appropriate reason by her on the graph shows that the number of Blackpink CDs sold in August is 2000 CD (figure 1, SP1-003 and SP1-004) from the data it can be concluded that the camper type female subject is able to answer level 1 question.

2. Mathematical literacy ability of SP number 2

A glant Ferris wheel is on the bank of a river. See the picture and diagram below.

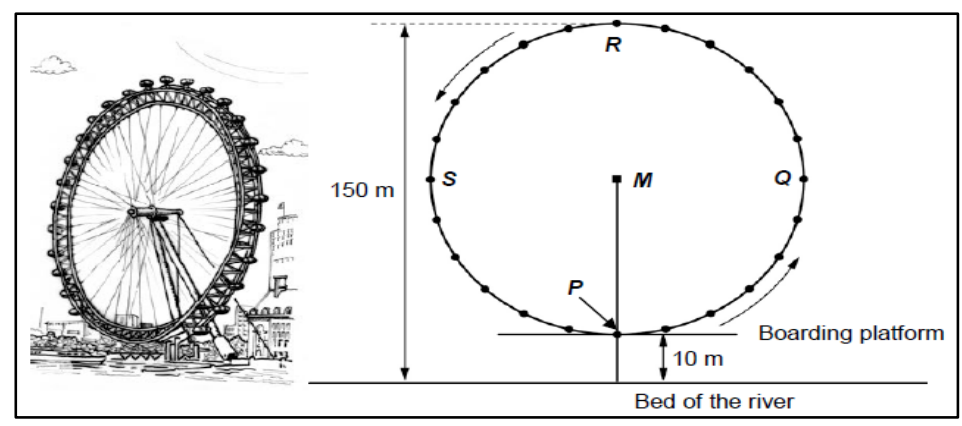

The Ferris wheel rotates at a constant speed. The wheel makes one full rotation in exactly 40 minutes. John starts his ride on the Ferris wheel at the boarding point, $\mathrm{P}$. where will John be after half an hour?



Figure 2. Female Student Answer to Question 2 


\section{The researcher questions and subject answers}

P2-001 : Now, question number 2. Do you understand the question?

SP2-001 : Yes sir

P2-002 : Whether the information on the question is complete to answer the question?

SP2-002 : Yes sir

P2-003 : What is the answer to question number 2?

SP2-003 : After half an hour, Doni is at point $\mathrm{R}$

P2-004 : Why answer at point R?

SP2-004 : According to the information on the problem, the wheel spins one full rotation in 40 minutes. This means that from point $P$ to $S$ it is 10 minutes, $\mathrm{S}$ to $\mathrm{R}$ is 10 minutes onwards. The wheel rotates one full turn in 40 minutes, so automatically 40 minutes return to point $\mathrm{P}$ then $\mathrm{P} 10$ minutes to, $\mathrm{S} 10$ minutes to $\mathrm{R}$ so John is at point R.

P2-005 : Why is Joni at point $\mathrm{R}$ ?

SP2-005 : Because on the statement about "After half an hour"

P2-006 : How many minutes is half an hour?

SP2-006 : 60 minutes (subject looks nervous)

P2-007 : How much is half an hour?

SP2-007 : Eh 60 minutes

P2-008 : Are you sure about your answer?

SP2-008 : No sir, it's wrong (the subject shook his head)

Following the data analysis process carried out in accordance with the students' mathematical literacy skills based on level 2. The subject's answer from the PISA test results and the interview excerpt in question number 2 is wrong, namely, after half an hour John is at point $R$, the correct answer should be after half an hour John is at point $S$, when answering the question the subject does not pay attention to the sound of the question that "the wheel rotates at a constant speed and counterclockwise" so that the answer from the subject is wrong because the subject answers clockwise and the female subject is wrong with the statement " half an hour "the subject assumed that half an hour was equal to 60 minutes. (Figure 2, SP2-003 and SP2-004) from the data, it can be concluded that the camper type female subject was unable to answer PISA level 2 questions correctly.

3. Mathematical literacy ability of SP number 3

Rizky works at a store that rents DVDs and Computer Games. At this store annual membership fee costs Rp.10.000,00. The DVD rental fee for members is lower than the fee for non-members, as shown in the following table: 


\begin{tabular}{cc}
\hline $\begin{array}{l}\text { Non-member rental fee } \\
\text { for one DVD }\end{array}$ & $\begin{array}{l}\text { Member rental fee } \\
\text { for one DVD }\end{array}$ \\
\hline Rp.3.200 & Rp. 2.500 \\
\hline
\end{tabular}

What is the minimum number of DVDs a member needs to rent to cover the cost of the membership fee? Show your work.

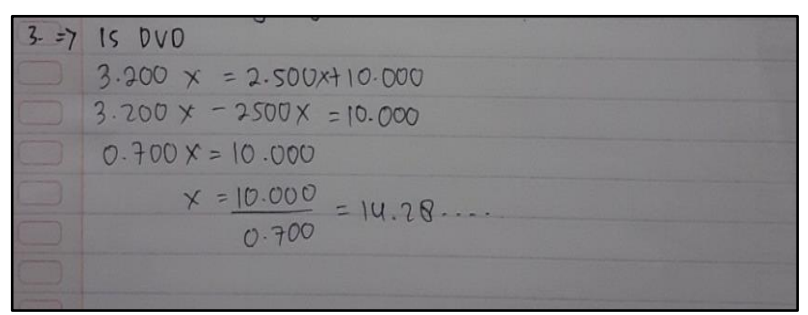

Figure 3. Female Student Answer to Question 3

\section{The researcher questions and subject answers}

P3-001 : Do you understand question number 3?

SP3-001 : Don't understand sir

P3-002 : Which one do you not understand? please try reading again

SP3-002 : : Rizky works in a shop that rents out DVDs and computer games. In this shop, the annual membership fee is Rp. 10,000.00. The DVD rental fee for members is lower than the fee for nonmembers, the non-member rental fee is 3200 while the membership fee is 2500 . What is the minimum number of DVDs a member must rent to cover the membership fee?

P3-003 : What is your answer?

SP3-003 : 15 DVD

P3-004 : How does it work? Explain the steps to do it

SP3-004 : (While pointing at the answer) this is (3200) for non-member fees, this is (2500) for my members plus the annual fee $(10,000)$, I continue to subtract it because if I move (move segments) it is less so the result is negative. So $3200-2500=10,000$

$0,700 x=10.000$

So $X=10.000$ divided by 0,700 , the result 14,28 , I conclude to be 15 DVD

P3-005 : Are you sure about your answer?

SP3-005 : Yes, sir. I'm sure

Following the data analysis process carried out in accordance with the students' mathematical literacy skills based on level 3. The subject answer to the test results and the interview excerpt in question number 3 is that the answer to the final result is not correct when rounding numbers 14.28 to 15 should be 14.28 is rounded down to 14 so the answer is 14 DVDs. The subject is correct in the 
problem work procedure (figure 3, SL3-003, SP3-004) from the data it can be concluded that the camper type female subject is able to answer PISA level 3 questions.

\section{b. Camper Type Male Subject (SL)}

1. Mathematical literacy ability SL number 1

In June 2020, the new CDs of the Blackpink and Adele were released. In February, the CDs of BTS and the Maroon 5 followed. The following graph shows the sales of CDs from June to November.

\section{Sales Graph}
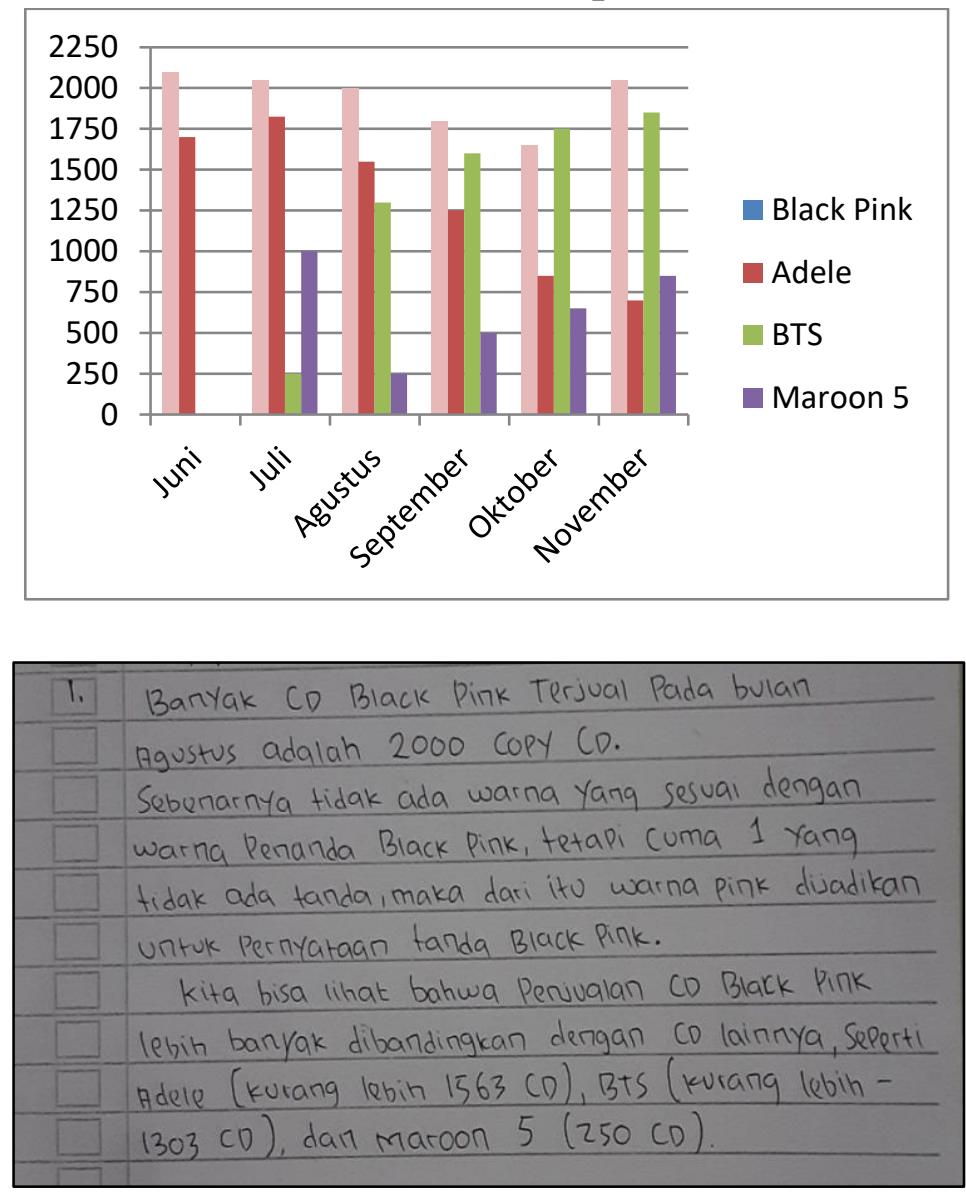

Figure 4. Male Student Answer to Question 1

\section{The researcher questions and subject answers}

P1-001 : Look at the question! Do you understand question number 1?

SL1-001 : Understand sir

P1-002 : Is the information in question number 1 clear?

SL1-002 : Clear

P1-003 : What is your answer to question number 1 ?

SL1-003 : My answer is that the number of Blackpink CD sold in August 
is 2000 copies of CD

P1-004 : What is the reason?

SL1-004 : Actually, there is no color that matches the color of the Blackpink marker, but only one that is not marked, therefore the pink color is used as a statement to sign Blackpink.

We can see that Blackpink's CD sales are more with other CDs, such as Adele about 1563 CD, BTS around 1303 CD, and Maroon 5250 CD.

P1-005 : So you answer everything based on what?

SL1-005 : Based on the table

P1-006 : Are you sure about your answer?

SL1-006 : Sure

Following the data analysis process carried out in accordance with the student's mathematical literacy skills based on level 1. subject answer to the test results and interview excerpts in question 1 is correct but the reasons presented are too long but the aims and objectives are the same according to the question information (figure 4, SL1-003, SL1-004) from the data it can be concluded that the camper type male subject is able to answer PISA level 1 questions.

2. Mathematical literacy ability SL number 2

A glant Ferris wheel is on the bank of a river. See the picture and diagram below.

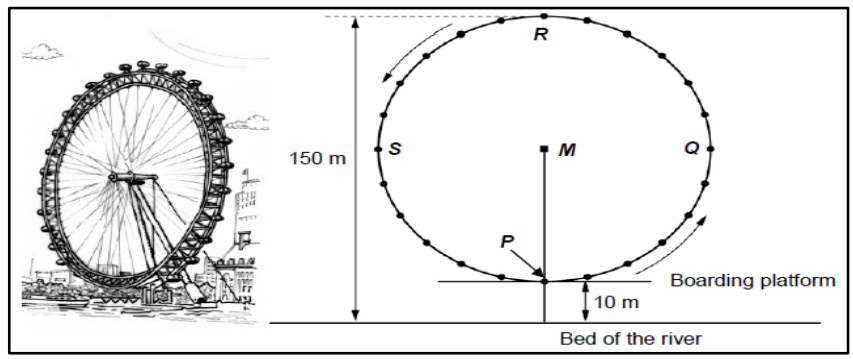

The Ferris wheel rotates at a constant speed. The wheel makes one full rotation in exactly 40 minutes. John starts his ride on the Ferris wheel at the boarding point, $\mathrm{P}$. where will John be after half an hour?

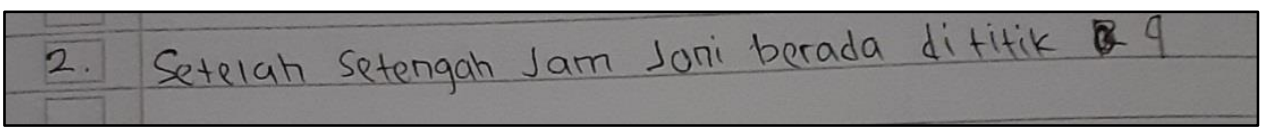

Figure 5. Male Student Answer to Question 2

\section{The researcher questions and subject answers}

P2-001 : Look at the question! Do you understand question number 2?

SL2-001 : Understand sir 
P2-002 : What is your answer to the question of number 2?

SL2-002 : My answer is after half an hour John was at point $P$

P2-003 : Please explain

SL2-003 : Because at point $P$ to $S 10, S$ to $R 20, R$ to $Q$ is 30 . So one round has 40 minutes

P2-004 : Are you sure about your answer?

SL2-004 : Yes sir

Following the data analysis process carried out in accordance with the student's mathematical literacy abilities based on level 2. The subject's answer from the test results and the interview excerpt in question number 2 is wrong so that the reasons presented are also wrong. Just like the female subject, the male subject also did not pay attention to the sound of the question that "the wheel rotates at a constant speed and counterclockwise" so that when answering the subject follows the clockwise direction. The male subject did not seem to understand the questions given (figure 5, SL2-002, SL2-003) from the data it can be concluded that the male subject of the camper type has not been able to answer PISA level 2 questions.

3. Mathematical literacy ability SL number 3

Rizky works at a store that rents DVDs and Computer Games. At this store annual membership fee costs Rp.10.000,00. The DVD rental fee for members is lower than the fee for non-members, as shown in the following table:

\begin{tabular}{cc}
\hline $\begin{array}{l}\text { Non-member rental fee } \\
\text { for one DVD }\end{array}$ & $\begin{array}{l}\text { Member rental fee } \\
\text { for one DVD }\end{array}$ \\
\hline Rp.3.200 & Rp. 2.500 \\
\hline
\end{tabular}

What is the minimum number of DVDs a member needs to rent so as to cover the cost of the membership fee? Show your work.

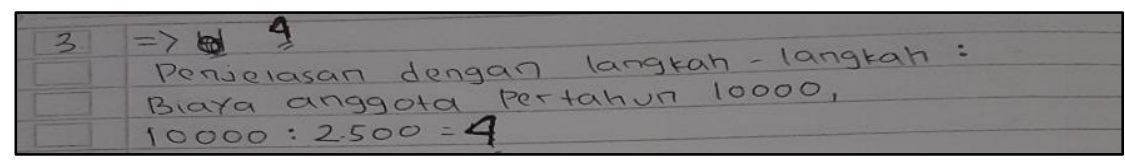

Figure 6. Male Student Answer to Question 3

\section{The researcher questions and subject answers}

P3-001 : Look at the question! do you understand question 3?

SL3-001 : Yes sir

P3-002 : What is your answer?

SL3-002 : 4

P3-003 : Why 4? Can you explain it?

SL3-003 : Because the annual membership fee is Rp. 10.000 so I divided Rp. 10.000 by Rp. 500 so the result is 4 
P3-004 : Are you sure about your answer?

SL3-004 : Yes sir, sure

Following the data analysis process carried out in accordance with the student's mathematical literacy skills based on level 3. The subject answer from the test results and the interview excerpt in question number 3 is not correct or wrong as well as the work procedure on the incorrect answer (figure 6, SL3-003) from the data it can be concluded that the camper type male subject has not been able to answer PISA questions level 3.

From the results of the data analysis above, it shows the literacy ability of each subject.

1. Mathematical literacy ability female student camper type

a. Mathematical literacy ability of female student camper type at level 1 category

In question number 1 which is PISA level 1 category, the subject is able to answer the question correctly and the reason is correct according to the information on the question. The subject converts the data from the bar chart into tables to make it easier to read, but this process takes a long time.

b. Mathematical literacy ability of female student camper type at level 2 category

In question number 2 which is the level 2 PISA category, the subject has not been able to answer the question correctly because the subject does not pay attention to all the statements and questions in the question, it seems the subject does not pay attention to the sound of the question "the wheel rotates at a constant speed and counterclockwise" so that the subject the woman answers clockwise. And also the subject mistakenly stated "half an hour" and the subject assumed half an hour $=60$ minutes. So that the mathematical literacy skills of the camper type female students in question number 2 are still lacking.

c. Mathematical literacy ability of female student camper type at level 3 category

In question number 3 which is the level 3 PISA category, the subject answers the question with appropriate and correct procedures but is slightly wrong at the conclusion of the answer given, the rounding result should be 14.28, not 15, answer question number 3 level 3. 


\section{Mathematical literacy ability male student camper type}

a. Mathematical literacy ability of male student Camper type at level 1 category

In question number 1 which is the level 1 PISA category, the subject is able to answer the question correctly and the reason is correct according to the information contained in the question.

b. Mathematical literacy ability of male student camper type at level 2 category

In question number 2 which is the level 2 PISA category, the subject has not been able to answer the question correctly. The subject has not been able to understand the contents of question number 2 properly so that the answers and reasons given are not correct.

c. Mathematical literacy ability of male student camper type at level 3 category

In question number 3 which is PISA level 3 category, the subject has not been able to answer the question correctly and the procedure for working on the answer to the question is also wrong.

\section{Similarities in Mathematical Literacy Ability Female and Male Students} of Camper Type

a. Mathematical literacy ability SP and SL level 1 category

SP and SL both could answer the question correctly and the right reason according to the information in the question.

b. Mathematical literacy ability SP and SL level 2 category

SP and SL answer questions with wrong answers. Both SP and SL do not pay attention to the sound of the question that "the wheel rotates at a constant speed and counterclockwise" so that SP and SL answer clockwise. SP during the interview admitted that he was in doubt about the answer.

c. Mathematical literacy ability SP and SL level 3 category

SP and SL both could answer questions and each can describe the reasons.

\section{Differences in The Mathematical Literacy Ability Female and Male students of Camper Type}

The following table shows the differences in mathematical Literacy Ability possessed by the female (SP) and male (SL) of camper type. 
Table 4. Differences in The Mathematical Literacy Ability Female and Male students of Camper Type

\begin{tabular}{|c|c|c|}
\hline Subject & $\begin{array}{l}\text { Female Subject of Camper Type } \\
\qquad(\mathrm{SP})\end{array}$ & $\begin{array}{l}\text { Male Subject of } \\
\text { Camper Type } \\
\text { (SL) }\end{array}$ \\
\hline $\begin{array}{l}\text { 1. Mathematical } \\
\text { literacy ability } \\
\text { PISA test level } 1\end{array}$ & $\begin{array}{l}\text { The female subject answered the } \\
\text { question by changing the bar } \\
\text { chart into a table form so that the } \\
\text { value of each Group Band was } \\
\text { easy to read }\end{array}$ & $\begin{array}{l}\text { Male subject } \\
\text { answered the } \\
\text { question by } \\
\text { estimating the } \\
\text { CD count of each } \\
\text { group Band }\end{array}$ \\
\hline $\begin{array}{l}\text { 2. Mathematical } \\
\text { literacy ability } \\
\text { PISA test level } 2\end{array}$ & $\begin{array}{l}\text { The subject has not been able to } \\
\text { answer question number } 2 \\
\text { correctly. The subject admitted } \\
\text { that he doubted the answer. The } \\
\text { subject seemed to understand the } \\
\text { problem, but the subject did not } \\
\text { pay attention to the sound of the } \\
\text { question which stated that "the } \\
\text { wheel is turning } \\
\text { counterclockwise" so that the } \\
\text { subject answered incorrectly. }\end{array}$ & $\begin{array}{l}\text { The subject has } \\
\text { not been able to } \\
\text { answer question } \\
\text { number } 2 \\
\text { correctly. The } \\
\text { subject looks not } \\
\text { familiar with the } \\
\text { problem }\end{array}$ \\
\hline $\begin{array}{l}\text { 3. Mathematical } \\
\text { literacy ability } \\
\text { PISA test level } 3\end{array}$ & $\begin{array}{l}\text { Subjects are able to answer } \\
\text { question number } 3 \text { correctly } \\
\text { according to the procedure. }\end{array}$ & $\begin{array}{l}\text { The subject has } \\
\text { not been able to } \\
\text { answer question } \\
\text { number } 3 \\
\text { correctly. }\end{array}$ \\
\hline
\end{tabular}

The results of this study indicate that female student has a higher ability to solve questions than the male student. In contrast with Halpern in Goodwin \& Friedman (2006) argues that boys have better intellectual abilities than girls. Boys are rational, independent, aggressive, achievement-oriented, and active. Meanwhile, girls are more proficient in reading and writing tasks because girls have a higher emotional level, give up easily, are passive and subjective, so they are weak in mathematics. While the results of this study indicated that female student has a better ability to solve problems than boys. The camper type female student was able to answer the level 1 and level 3 questions correctly and for the right reasons, while the camper type male students were only able to answer the level 1 questions correctly. For level 2 questions, female students interpreted the questions incorrectly, but during the interview, it was seen that the camper type 
of female students understood the level 2 questions. Meanwhile, the camper type male students did not seem to understand the level 2 and level 3 questions, in contrast to Sutrisno and Adirakasiwi (2019), the results showed that the literacy mathematical ability of male student was higher than the literacy abilities of female students. Differences in research result can occur because only takes two subjects and different locations so that it cannot be generalized.

\section{CONCLUSION}

Based on the research results and data analysis that have been presented, the camper type female subject has high mathematical literacy skills for level 1, level 2, and level 3. This is indicated by the subject's ability to answer questions. Even though in number 2 for the category of PISA level 2 questions, the subject answers wrong but the subject is aware of the mistake and the subject understood the PISA question. The male subject of the camper type has low mathematical literacy ability for level 1, level 2, and level 3, this is indicated by the subject's ability to answer questions. The camper type male subject was only able to answer 1 of 3 questions correctly, namely question number 1 . The difference in the ability of the two subjects is very visible from their respective answer sheets, the female subject answers neatly and structurally while the male subject answers the unstructured answer sheet, the male subject first answers question number 3 then works on question number 2. Mathematical literacy ability of camper type female subject was higher than the camper type male subject.

\section{REFERENCES}

Abidin, Y., Mulyati, T., \& Yunansah, H. (2017). Pembelajaran literasi, strategi meningkatkan kemampuan literasi matematika, sains, membaca dan menulis. Jakarta: Bumi Aksara.

Daryanto, \& Syaiful, K. (2016). Pembelajaran Abad 21. Yogyakarta: Gava Media.

Dorn, L., \& Jones, T. (1980). Apprenticeship in Literacy, Second Edition. Stenhouse Publisher. Retrieved from https://www.stenhouse.com/content/ apprenticeship-literacy-second-edition.

Goodwin, R. D., \& Friedman, H. S. (2006). Health status and the five-factor personality traits in a nationally representative sample. Journal of Health Psychology, 11(5), 643-654. https:/ / doi.org/10.1177/1359105306066610.

Kemendikbud. (2016). Peringkat dan capaian pisa indonesia mengalami peningkatan. Retrieved from https://www.kemdikbud.go.id/main/blog/2016/12/ peringkat-dan-capaian-pisa-indonesia-mengalami-peningkatan.

Khoirudin, A., Styawati, R. D., \& Nursyahida, A. (2017). Profil kemampuan 
literasi matematika siswa berkemampuan matematis rendah dalam menyelesaikan soal berbentuk PISA. AKSIOMA: Jurnal Matematika Dan Pendidikan Matematika, 8(2), 33-42. https://doi.org/10.26877/aks.v8i2. 1839.

Lange, J. de. (2006). Mathematical literacy for living from OECD-PISA perspective. Tsukuba Journal of Educational Study in Mathematics, 25, 1335. Retrieved from http://www.human.tsukuba.ac.jp/ mathedu/2503. pdf.

Mahdiansyah, \& Rahmawati. (2014). Literasi matematika siswa pendidikan menengah: Analisis menggunakan desain tes internasional dengan konteks Indonesia. Jurnal Pendidikan Dan Kebudayaan, 20(4), 452-469. https:// doi.org/10.24832/jpnk.v20i4.158.

National Council of Teachers of Mathematics. (2000). Principles and standards for school mathematics. Reston, VA: NCTM.

OECD. (2014). PISA 2012 result: what student know and can do (volume I, revised edition, February 2014) student performance in mathematics, reading, and science. Paris: OECD Publishing. Retrieved from https://www.oecdilibrary.org/education/ pisa-2012-results-what-students-know-and-cando-volume-i-revised-edition-february-2014_9789264208780-en.

OECD. (2015). PISA 2015 assessment and analytical framework. Paris: OECD Publishing. Retrieved from https://www.oecd.org/publications/pisa2015-assessment-and-analytical-framework-9789264281820-en.htm.

Ojose, B. (2011). Mathematics literacy: Are we able to put the mathematics we learn into everyday use? Journal of Mathematics Education, 4(1), 89-100. Retrieved from http://educationforatoz.com/images/8.Bobby_Ojose_-_Mathematics_Literacy_Are_We_Able_To_Put_The_Mathematics_We_ Learn_Into_Everyday_Use.pdf.

Pasiak, T. (2004). Membangunkan raksasa tidur: Optimalkan kemampuan otak anda dengan metode alissa. Jakarta: Gramedia.

Setiawan, H., Dafik, D., \& Lestari, N. D. S. (2014). Soal matematika dalam PISA kaitanannya dengan literasi matematika dan keterampilan berpikir tingkat tinggi. Prosiding Seminar Matematika Dan Pendidikan Matematik, 1(1). Retrieved from https:/ / jurnal.unej.ac.id/index.php/psmp/article/ view/955.

Suryaprani, M. W., Suparta, I. N., \& Suharta, I. G. P. (2016). Hubungan jenis kelamin, literasi matematika, dan disposisi matematika terhadap prestasi belajar matematika peserta didik SMA Negeri di Denpasar. Prosiding Seminar Nasional MIPA. Universitas Pendidikan Ganesa Singaraja, Denpasar.

Sutrisno, U., \& Adirakasiwi, A. G. (2019). Analisis kemampuan literasi matematis pada soal berorientasi pisa konten uncertainty and data berdasarkan jenis kelamin. Prosiding Seminar Nasional Matematika Dan 
Pendidikan Matematika Sosiomedika 2019. Universitas Singaperbangsa, Karawang.

Syawahid, M., \& Putrawangsa, S. (2017). Kemampuan literasi matematika siswa SMP ditinjau dari gaya belajar. Jurnal Tadris Matematika, 10(2), 222 - 240. https:// doi.org/10.20414/Betajtm.V10i2.121.

Wardhani, S. (2005). Pembelajaran dan penilaian aspek pemahaman konsep, penalaran dan komunikasi, pemecahan masalah. (Online). Retrieved from http:// p4tkmatematika.org/file/P\%0ARODUK/PAKET FASILITASI/SMP/St a\%0Andar Penilaian Pendidikan.pdf.

White, A. L. (2018). Australian mathematics literacy perspectives: assessment. Southeast Asian Mathematics Education Journal, 8(1), 31-42. https:// doi.org/10.46517/ seamej.v8i1.65.

Wicaksana, Y., Wardono, \& Ridlo, S. (2017). Analisis kemampuan literasi matematika dan karakter rasa ingin tahu siswa pada pembelajaran berbasis proyek berbantuan. Unnes Journal of Mathematics Education Research, 6(2). Retrieved from https://journal.unnes.ac.id/sju/index. $\mathrm{php} /$ ujmer/article/view/20475. 